Shackleton, N., 1967. Oxygen Isotope Analyses and Pleistocene Temperatures reassessed, Nature. 215, 15.

Sugden, W., 1963. Some aspects of sedimentation in the Persian Gulf. Sediment Petrol. 33, 2, 355.

Sharma, T. and Clayton, R. N., 1965. Measurements of $\mathrm{O}^{18} / \mathrm{O}^{16}$ ratios of total oxygen from carbonates. Geochim. Chosmochim. Acta. 29, 1347.
Ruggieri, G. 1967. The Miocene and later evolution of the Mediterranean Sea. Sipt. Assoc. Publ. 1, 283.

Ruggieri, G. and Greco, A., 1965. Studi geologici e paleontologici su capo Milazzo con particulare regardo al Milazziano. Geol. Romona. 1, 41.

Russell, K. L. Deffreyes, K. S., Fowler, G. A. and Lloyd, R. M., 1967. Marine Dolomite of Unusual Isotopic Composition, Science. 155 n $^{\circ} 3759,189$.

\title{
30.3. STABLE OXYGEN AND CARBON ISOTOPE VARIATIONS IN BULK CARBONATES FROM LATE MIOCENE TO PRESENT, IN TYRRHENIAN BASIN - SITE 132
}

\author{
James R. Lawrence, Lamont-Doherty Geological Observatory, Columbia University, Palisades, New York
}

\section{INTRODUCTION}

This investigation was undertaken to determine to what degree the $0^{18} / \mathrm{O}^{16}$ and $\mathrm{C}^{13} / \mathrm{C}^{12}$ ratios of full carbonate sediments represent depositional conditions versus diagenetic conditions. If appreciable diagenesis can be discounted, then the measured isotopic values should reflect the surface water temperature at the time of growth of the carbonate organisms and the $0^{18} / \mathrm{O}^{16}$ and $\mathrm{C}^{13} / \mathrm{C}^{12}$ content of the surface waters. If, on the other hand, significant isotopic exchange has occurred during diagenesis, the isotopic values should yield information about the temperatures and mechanisms of diagenesis.

The sediments from Site 132 consist of evaporites of Miocene age overlain unconformably by a continuous section of pelagic oozes of Pliocene to Recent age (see Chapter 13). The Miocene evaporites consist mostly of gypsum, dolomite, calcite and silicate detritus and contain, in several horizons, brackish water fossils. These sediments have undergone lithification and recrystallization to a moderate degree since deposition. The Plio-Pleistocene oozes consist of coccoliths (70-95\%) and foraminiferal (5-30\%) shells formed in surface and near surface waters, plus a variable amount of silicate detritus (see Figure 1). Very little lithification and recrystallization has taken place in these younger sediments (see Chapter 13).

Bulk samples, representing one centimeter horizons at 19 intervals throughout the entire core, were analyzed for $\mathrm{O}^{18 / \mathrm{O}^{16}}$ and $\mathrm{C}^{13} / \mathrm{C}^{12}$ content of the carbonate fraction by the method described by McCrea (1950). All $\mathrm{C}^{13} / \mathrm{C}^{12}$ and $0^{18 / 016}$ analyses are reported in the $\delta$-notation with $\delta$-values being reported with respect to PDB and SMOW, respectively.

\section{RESULTS AND DISCUSSION}

Variations in the $\mathrm{CaCO}_{3}$ content of sediments from Site 132 are shown in Figure 1. There is an abrupt increase in

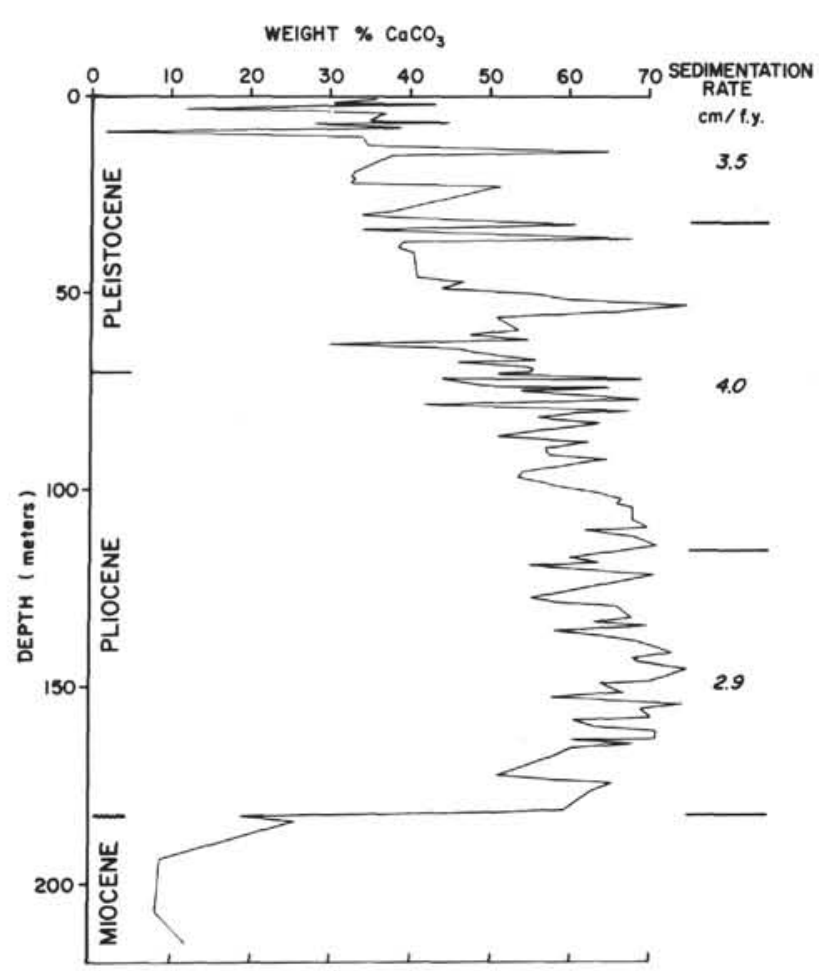

Figure 1. Weight per cent of $\mathrm{CaCO}_{3}$ in the sediments from Site 132, Leg 13 plotted as a function of depth. The average sedimentation rates in centimeters per thousand years are also shown.

$\mathrm{CaCO}_{3}$ content of the sediments across the MiocenePliocene unconformity. This is not unreasonable considering the drastic change from an evaporite sequence to normal marine pelagic oozes.

The $\mathrm{CaCO}_{3}$ content of the Pliocene sediments is relatively uniform, with a decrease in the upper Pliocene which continues into the Pleistocene. Comparison of the changes 
in $\mathrm{CaCO}_{3}$ content with the changes in total sedimentation rate suggests, on an average basis, a twofold increase in the amount of silicate detritus going from the late Pliocene to the Pleistocene. Also, the magnitude of shorter term fluctuations of $\mathrm{CaCO}_{3}$ content are much greater in the Pleistocene than in the Pliocene. These variations in $\mathrm{CaCO}_{3}$ content probably reflect the effects of continental glacial cycles in Europe and Asia during the Pleistocene.

The isotopic data and $\mathrm{CaCO}_{3}$ contents of the analyzed samples are illustrated in Figures 2 and 3. In the discussion which follows, it is assumed that there are no large changes in $0^{18} / 0^{16}$ or $\mathrm{C}^{13} / \mathrm{C}^{12}$ due to changes in the biologic makeup of the carbonate.

The largest changes in $\mathrm{O}^{18} / \mathrm{O}^{16}$ and $\mathrm{C}^{13} / \mathrm{C}^{12}$ are observed across the Miocene-Pliocene unconformity. The $\mathrm{O}^{18} / \mathrm{O}^{16}$ and $\mathrm{C}^{13} / \mathrm{C}^{12}$ of most of the samples above the boundary are in the range expected for $\mathrm{CaCO}_{3}$ in equilibrium with surface waters similar in temperature and isotopic composition to those of the Mediterranean Sea today (see Figures 2 and 3). The samples below the boundary are, in contrast, distinctly depleted in $\mathrm{O}^{18}$ and $\mathrm{C}^{13}$, which strongly suggests that the water in which the carbonates were formed, or recrystallized, was meteoric in origin. Also, the fact that the isotopic values display a sharp break over a

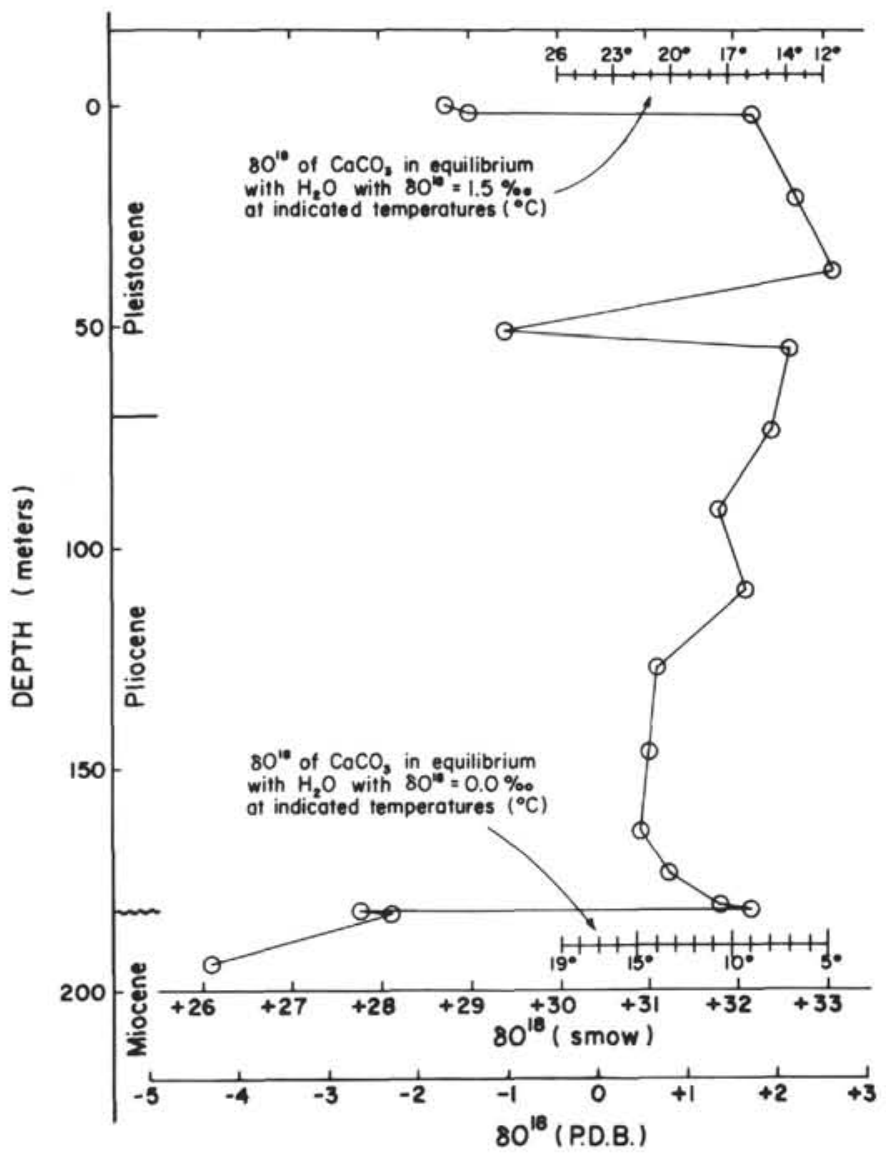

Figure 2. $\delta 0^{18}$ of the bulk carbonate from Site 132, Leg 13 sediments. The temperature- $\delta O^{18}$ scales shown were calculated using the carbonate temperature scale of Epstein et al. (1953). One is based on $\delta \mathrm{O}^{18} \mathrm{H}_{1} \mathrm{O}=+1.5$ percent representing $\mathrm{CaCO}_{3}$ in equilibrium with presentday surface waters in the Mediterranean; the other on $\delta \mathrm{O}^{18} \mathrm{H}_{1} \mathrm{O}=0.0$ per mills representing $\mathrm{CaCO}_{3}$ in equilibrium with Atlantic Ocean Deep Water.

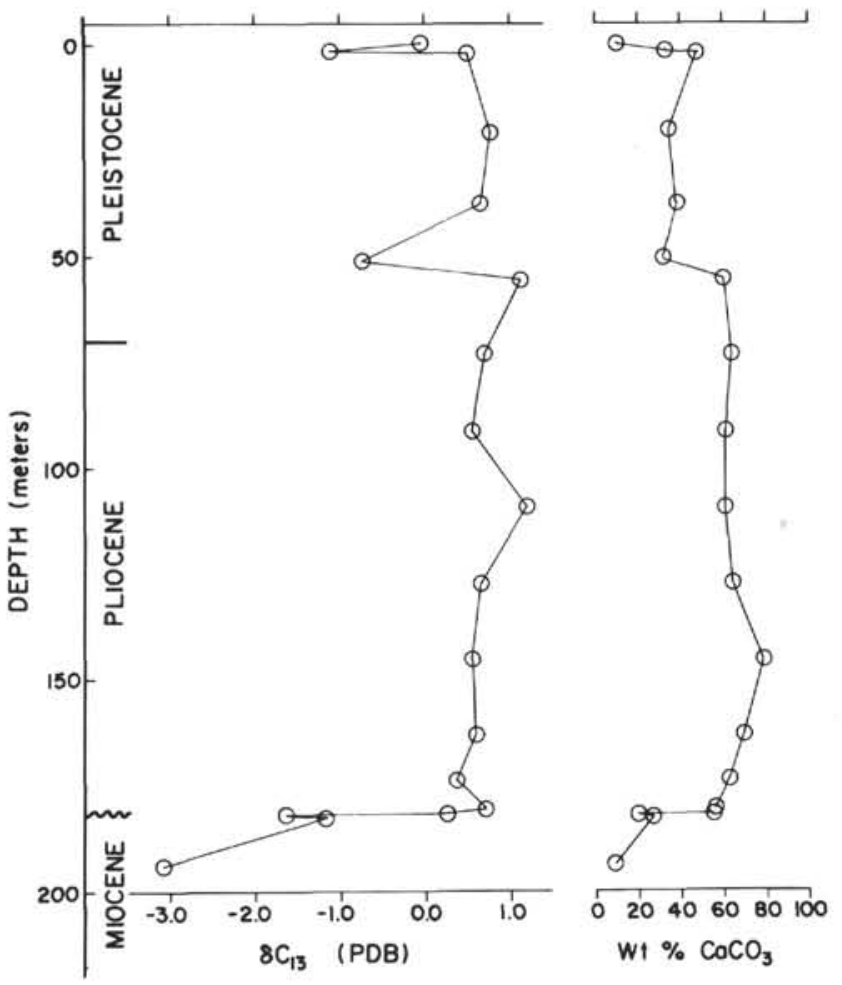

Figure 3. $\delta C^{13}$ of the bulk carbonate from Site 111, Leg 13 sediment. The weight per cent of $\mathrm{CaCO}_{3}$ in the isotopically analyzed samples is also shown.

$4 \mathrm{~cm}$ interval (the two samples at the Mio-Pliocene boundary are only $4 \mathrm{~cm}$ apart) suggests that no large degree of isotopic change as a result of diagenesis has occurred since the deposition of the Pliocene sediments.

Three samples in the Pleistocene, two sapropel horizons ${ }^{1}$ (at 2 and $53 \mathrm{~m}$ ) and a layer containing a high percentage of silicate detritus (at $1 \mathrm{~m}$, the peak of the Wisconsin glacial stage), are depleted in $\mathrm{O}^{18}$ and $\mathrm{C}^{13}$ compared to the bulk of the Plio-Pleistocene samples. These large decreases are probably due mostly to influxes of $\mathrm{O}^{18}$ and $\mathrm{C}^{13}$ depleted glacial melt waters into the surface waters of the Mediterranean. Part of the decrease in $0^{18 / 0^{10}}$ may be due to a warming of surface waters, since the sapropel horizons can be correlated with warming trends following glacial maximums (see Chapter 46).

The remainder of the Plio-Pleistocene samples exhibit no obvious trends in $\mathrm{C}^{13} / \mathrm{C}^{12}$ but do show significant changes in $0^{18 / O^{16}}$. There is a decrease in $\delta \mathrm{O}^{18}$ of $1^{\circ} \%$ over a period of 300,000 years, starting with the sudden appearance of pelagic oozes in the late Pliocene. This could be attributed to a warming of the surface waters of the Mediterranean of from $4^{\circ}$ to $5^{\circ} \mathrm{C}$, to a decrease in the $\delta 0^{18}$ of the surface waters of $1 \%$, or to a combination of the two factors.

Paleontological evidence suggests the sudden appearance of pelagic oozes was the result of a sudden influx of cold

\footnotetext{
${ }^{1}$ Sapropels are organic-rich sediments which may have been formed during eutrophication of Mediterranean surface waters, perhaps associated with an influx of water from the Black Sea.
} 
Atlantic Deep Water. The initial $0^{18 / 0^{16}}$ of the Mediterranean surface waters would be expected to be free of influence from the Atlantic source. Subsequent excess evaporation in the Mediterranean would increase the $\delta \mathrm{O}^{18}$ of the surface waters. The observed progressive decrease in the $\delta 0^{18}$ of the carbonate from $+32 \%$ to $+31 \%$ could only be brought about if temperature effects overrode those of the isolation. Consequently the $4^{\circ}$ to $5^{\circ} \mathrm{C}$ inferred warming is a minimum value.

From the Late Pliocene to the Pleistocene, there is a 1.5 to $2 \%$ increase in the $\delta \mathrm{O}^{18}$ of $\mathrm{CaCO}_{3}$. If no large isotopic changes had taken place as a result of diagenesis, this could be attributed to: (a) an increase in the $\delta \mathrm{O}^{18}$ of the surface waters of 1.5 to $2 \%$ as a result of progressive isolation of the Mediterranean from the Atlantic (see Chapter 47.4), (b) to a cooling of the surface waters by $6^{\circ}$ to $9^{\circ} \mathrm{C}$, or (c) to a combination of both factors. It is probable that both cooling and an increase in the $\delta 0^{18}$ of the surface waters occurred with an increase in glaciation. An increase in glaciation is consistent with dropping temperatures. But also, increased glacial uptake of water would drop sea level and decrease circulation between the Atlantic and the Mediterranean. Increased isolation of the Mediterranean would have a greater effect on increasing the $018 / 0^{16}$ of the Mediterranean surface waters.
The variations in $0^{18 / O^{16}}$ and $\mathrm{C}^{13} / \mathrm{C}^{12}$ of the bulk carbonate at Site 132 are consistent with changes in surface water temperatures or with $\mathrm{O}^{18} / \mathrm{O}^{16}$ and $\mathrm{C}^{13} / \mathrm{C}^{12}$ variations in the surface waters as inferred from physical or paleontological changes in the sediment. In addition, sharp changes in $\mathrm{O}^{18 / \mathrm{O}^{16}}$ and $\mathrm{C}^{13} / \mathrm{C}^{12}$ occur over short time intervals in the sediments. Isotopic exchange or recrystallization of the bulk carbonate would tend to smooth such sharp isotopic gradients. These facts suggest that the isotopic values of most of the carbonate, with the exception of the Miocene sediments, is largely unaffected by diagenesis. Isotopic studies on individual carbonate fossils should verify this and determine to what degree changes in biologic makeup of the carbonate portion of the sediments (ignored in this discussion) have determined the $0^{18 / 0^{16}}$ and $\mathrm{C}^{13} / \mathrm{C}^{12}$ of the bulk carbonate.

Lamont-Doherty Geological Observatory Contribution No. 1860 .

\section{REFERENCES}

Epstein, S., Buchbaum, R., Lowenstam, H. A. and Urey, H. C., 1953. Revised carbonate-water isotopic temperature scale. Bull. Geol. Soc. Am 64, 1315.

McCrea, J. M., 1950. The isotopic chemistry of carbonates and a paleotemperature scale. J. Chem. Phys. 18, 849.

\title{
30.4. OXYGEN ISOTOPIC COMPOSITION OF BENTHONIC AND PLANKTONIC FORAMINIFERA OF EARLIEST PLIOCENE AGE AT SITE 132 - TYRRHENIAN BASIN
}

\author{
J. Van Donk and T. Saito, Lamont-Doherty Geological Observatory of Columbia University, Palisades, New York \\ and \\ N. J. Shackleton, Sub-Department of Quaternary Research, University of Cambridge, Cambridge, England
}

\section{INTRODUCTION}

Although it has been shown that some foraminifera do not deposit calcium carbonate in isotopic equilibrium with the surrounding water, the deviations noted are relatively small (up to $-1.0 \%$ ). For this reason it was considered worthwhile to analyse specimens of both benthonic and planktonic foraminifera from a single sample of pelagic ooze of earliest Pliocene age from Site $132\left(40^{\circ} 15.7^{\prime} \mathrm{N}\right.$; $11^{\circ} 26.5^{\prime} \mathrm{E}$, depth $2835 \mathrm{~m}$ ). It was hoped to obtain information about the structure of the Mediterranean water mass following re-introduction of marine conditions at the end of the late Miocene "crisis of salinity".

A quarter core section from 52 to $75 \mathrm{~cm}$ in Section 4 of Core 20 was sampled and washed. The sample interval is from a level only a few meters above the Miocene/Pliocene boundary (see Chapter 47 ).

\section{RESULTS}

\section{Benthonic Foraminifera}

The sample of benthonic foraminifera had a weight of about micrograms. It was roasted in vacuo before analysis at the University of Cambridge. Carbon dioxide was released by the action of 100 per cent orthophosphoric acid in vacuo at $50^{\circ} \mathrm{C}$, and it was analysed in a double-collecting mass spectrometer. Results were calibrated by the analysis of standard carbonates in identical conditions. The result (relative to the PDB standard) was:

$$
\begin{aligned}
& \delta \mathrm{O}^{18}=(+0.3 \pm 0.1)^{\circ} \% \\
& \delta \mathrm{C}^{13}=(+0.7 \pm 0.1)^{\circ} \%
\end{aligned}
$$

The analytical method is routine in this laboratory; the quoted uncertainty represents the standard deviation 